\title{
Earthen Plasters Based on Illitic Soils from Barrocal Region of Algarve: Contributions for Building Performance and Sustainability
}

\author{
José Lima ${ }^{1, a}$, Paulina Faria ${ }^{2, b}$ and António Santos Silva ${ }^{3, c}$ \\ ${ }^{1}$ Faculty of Architecture, University of Lisbon, 1349-055 Lisboa, Portugal \\ ${ }^{2}$ Dept. of Civil Engineering, Universidade NOVA de Lisboa, 2829-516 Caparica and CERIS - Civil \\ Engineering Research and Innovation for Sustainability, Universidade de Lisboa, 1049-001 Lisboa \\ ${ }^{3}$ Materials Department, National Laboratory for Civil Engineering, Avenida do Brasil, 101, \\ 1700-066 Lisboa, Portugal \\ ajose.lima.ferreira@gmail.com, ${ }^{b}$ paulina.faria@fct.unl.pt, cssilva@Inec.pt
}

Keywords: Earth-based plasters, illitic soils, clay hygroscopicity, clay mineralogy, relative humidity, dynamic adsorption, moisture buffering.

\begin{abstract}
Clayish earth-based mortars can be considered eco-efficient products for indoor plastering since they can contribute to improve important aspects of building performance and sustainability. Apart from being products with low embodied energy when compared to other types of mortars used for interior plastering, mainly due to the use raw clay as natural binder, earth-based plasters may give a significant contribution for health and comfort of inhabitants. Due to high hygroscopicity of clay minerals, earth-based mortars present a high adsorption and desorption capacity, particularly when compared to other type of mortars for interior plastering. This capacity allows earth-based plasters to act as a moisture buffer, balancing the relative humidity of the indoor environment and, simultaneously, acting as a passive removal material, improving air quality. Therefore, earth-based plasters may also passively promote the energy efficiency of buildings, since they may contribute to decreasing the needs of mechanical ventilation and air conditioning. This study is part of an ongoing research regarding earth-based plasters and focuses on mortars specifically formulated with soils extracted from Portuguese 'Barrocal' region, in Algarve sedimentary basin. This region presents high potential for interior plastering due to regional geomorphology, that promote the occurrence of illitic soils characterized by a high adsorption capacity and low expansibility. More specifically, this study aims to assess how clayish earth and sand ratio of mortars formulation can influence the physical and mechanical properties of plasters. For this assessment four mortars were formulated with different volumetric proportions of clayish earth and siliceous sand. The results from the physical and mechanical characterization confirmed the significantly low linear shrinkage of all the four mortars, as well as their extraordinary adsorption-desorption capacity. These results presented a positive correlation with mortars' clayish earth content and are consistent with the mineralogical analysis, that confirmed illite as the prevalent clay mineral in the clayish earth used for this study. Regarding mechanical resistance, although the promising results of the adhesion test, the flexural and compressive strength results suggest that the mechanical resistance of these mortars should be slightly improved. Considering the present results the mortars mechanical resistance improvement may be achieved through the formulation of mortars with higher clayish earth content, or alternatively, through the addition of natural fibers to mortars formulation, very common in this type of mortars. Both those options will be investigated in future research.
\end{abstract}

\section{Introduction}

Earth-based mortars can be considered eco-efficient products for indoor plastering since they can contribute to improve some important aspects of building performance related to health and comfort of inhabitants, as well as building sustainability. 
Improvements on building life cycle sustainability can be achieved through the use of earth-based mortars mainly due to its low embodied energy. That derives from the use of raw clay as a natural binder, without the need of any heat treatment, and from wide availability of local resources of clayish earth all over the globe, allowing the mitigation of ecological impact of long distance transportations [1]. Another positive contribution of earth-based mortars for building life cycle sustainability comes from the fact that earth-based mortars, produced without addition of any chemical stabilizer like cement or lime, can be easily recycled, just with low consumption of mechanical energy for grinding and the addition of water. Furthermore the use of clayish earth as raw material does not directly lead to any pollutant emissions during building life cycle, therefore mitigating contamination hazards even in an eventual end of life disposal [2].

Due to high hygroscopicity of the clay minerals [3,4], earth-based mortars present a high adsorption and desorption capacity, particularly when compared to other type of mortars for interior plastering [2]. This capacity allows earth-based plasters to act as a moisture buffer, contributing to balance the relative humidity of the indoor environment of buildings $[2,5,6]$.

This high humidity buffering capacity of earth-based plasters promotes the comfort and health of inhabitants. Firstly because a high relative humidity environment increase the discomfort associated with the perception of heat or cold [7]. Secondly because, by balancing the relative humidity of the indoor environment, earth-based plasters contribute, in one hand, to mitigate health conditions associated with high relative humidity, like infections, allergies or asthma; in another hand, contribute also to mitigate the probability of mucosal membranes irritation and inflammation associated to exceedingly dry indoor environments [8].

Earth-based plasters may also contribute to indoor air quality since clay can act as a passive removal material (PRM), lowering indoor ozone concentrations, and therefore lowering the probability of occurrence of indoor ozone reaction with other building materials. This may lead to lower concentrations of oxidized reactions products, which could be toxic and irritating to mucosal membranes and other tissues $[9,10]$.

Considering these earth-based plasters contribution for comfort perception and air quality of indoor environment of buildings, is therefore expectable that their use may also passively promote the energy efficiency of buildings, since they may contribute to decreasing the needs of mechanical ventilation and air conditioning.

Despite the increase of international interest in earth-based plasters there is still no European standards for this type of mortars. However, in Germany, the Deutsches Institut für Normung (DIN) recently released DIN 18947 [11], a national standard specifically devoted to earth-based mortars. Thenceforth that standard has been followed by several scientific studies regarding the assessment of mechanical and physical properties of this type of mortars [12,13,14,15].

As part of an ongoing research regarding earth-based plasters the present study also follows that DIN standard for the assessment of physical and mechanical properties of earth-based plasters specifically formulated with clayish earth extracted from 'Barrocal' region in Algarve, in southern Portugal, which have been revealing a high potential for interior plastering [14]. Specifically this study aims to assess how the ratio of clayish earth and sand defined in mortars formulation can influence physical and mechanical properties of plasters. This ratio play an important role on earth-based plasters performance, since it is expectable that formulations with higher concentration of clayish earth maximize plasters moisture buffering capacity, but simultaneously increase probability of occurrence of shrinkage cracking during the plaster drying phase.

The «Barrocal» region is set in the highest area of the Algarve sedimentary basin and presents a rugged topography with sloping valleys and ridge lines. It comprises essentially an extensive area of calcite and dolomite rocks along with carbonated terrains, formed in the Triassic and Jurassic periods of the Mesozoic era, extending from West to East, throughout the central belt of the Algarve [16]. The rugged relief of this region is partially promoted by northern constraint caused by the Iberian massif, a geologic formation from the Carboniferous period of the Paleozoic, and also, and not less important, due to the differential erosion of hard rocks and soft rocks, where the hardness of limestone and 
dolomite contrasts with the softness of marls. This erosion process, as well along with the karstification of the limestone and dolomite rocks, allowed the formation of an extensive variety of clayish soils in this region $[17,18]$.

Most probably due to the significant availability of raw clay the «Barrocal» region presents throughout history the largest number of clay quarries of southern of Portugal, whose role has been primarily the supply of raw material for local manufacturers of tiles, bricks and pottery [4]. In $1985 \mathrm{a}$ first study concerning the characterization of the clay quarries of Algarve region was published by a multidisciplinary team of researchers from governmental institutions [19]. This work covered a systematic study of 17 exploration zones of the clay quarries, either in activity or already abandoned at the time. The study comprised a detailed analysis of the lithology of each exploration zone, as well as the sampling of different clay layers from each quarry. The samples were subsequently analyzed in laboratory in order to assess their mineralogy and chemical and mechanical characterization. For each one of the clay quarries studied the researchers provide a detailed lithological log, including the quarry chronostratigraphy, the precise geographic coordinates and the mineralogical predominant composition for each clay layer sampled. Table 1 shows this information aggregated and summarized and Figure 1 shows the location of each clay quarry studied superimposed to the lithological map of the Algarve region.

Table 1 - Characterization of the clay quarries of Algarve region in 1985 (aggregated data from [19])

\begin{tabular}{|c|c|c|c|c|c|c|}
\hline$\overline{\text { Ref. }}$ & Municipality & Exploration zone / clay quarry & $\begin{array}{c}\text { Chronostratigraphy } \\
\text { (1) }\end{array}$ & $\begin{array}{l}\text { Mineralogy } \\
\text { (2) }\end{array}$ & $\begin{array}{l}\text { Longitude } \\
\text { (3) }\end{array}$ & $\begin{array}{l}\text { Latitude } \\
\text { (3) }\end{array}$ \\
\hline 1 & Aljezur & Ponto Alto $\mathrm{n}^{\circ} 2$ (AJZ-2) & Pliocene & $\mathrm{I} / \mathrm{Cc}+\mathrm{I} / \mathrm{I}+\mathrm{K} / \mathrm{I}$ & 141800.00 & 41600.00 \\
\hline 2 & Vila do Bispo & Vale do Boi $n^{\circ} 1$ & Rhaetian / Hettangian & $\mathrm{I}+\mathrm{K}$ & 139700.00 & 14200.00 \\
\hline 3 & Lagos & José Bravo (3697/LGS-2) & Carboniferous & I & 142800.00 & 21000.00 \\
\hline 4 & Lagos & Barão (3698/LGS-3) & Rhaetian / Hettangian & $\mathrm{I}+\mathrm{K}$ & 143400.00 & 20500.00 \\
\hline 5 & Lagos & Barrada Redonda (3699/LGS-1) & Rhaetian / Hettangian & $\mathrm{I}+\mathrm{Dol}$ & 152000.00 & 22100.00 \\
\hline 6 & Silves & Sítio dos Vales (SVL-32) & Cretaceous & $\mathrm{I} / \mathrm{I}, \mathrm{Q}$ & 183800.00 & 21200.00 \\
\hline $7 \mathrm{a}$ & Silves & Barreia dos Vales (3493/SVL-3) & Cretaceous & $\mathrm{I}+\mathrm{Q}$ & 185100.00 & 20700.00 \\
\hline $7 \mathrm{~b}$ & Silves & Vales n² (3730/SVL-7) & Cretaceous & $\mathrm{I}+\mathrm{Q}$ & 185400.00 & 20800.00 \\
\hline $7 \mathrm{c}$ & Silves & Vales nº7 (3813/SVL-4) & Cretaceous & $\mathrm{I}+\mathrm{Q}$ & 185200.00 & 21000.00 \\
\hline $7 \mathrm{~d}$ & Silves & Vales n³ (381/SVL-5) & Cretaceous & $\mathrm{I}+\mathrm{Q}$ & 185600.00 & 20900.00 \\
\hline 8 & Silves & Vale de Silves (SVL-31) & Cretaceous & $\mathrm{I}, \mathrm{Q}$ & 189700.00 & 22100.00 \\
\hline $9 \mathrm{a}$ & Albufeira & Mem Moniz (ABF-4) & Cretaceous & $\mathrm{I}, \mathrm{Q}$ & 192300.00 & 22300.00 \\
\hline $9 b$ & Albufeira & Vale de Pegas (3855/ABF-5) & Cretaceous & $\mathrm{I}, \mathrm{Q}$ & 191000.00 & 22000.00 \\
\hline 10 & Albufeira & Barreiros (ABF-31) & Quaternary & $\mathrm{I}+\mathrm{Q}$ & 194500.00 & 24500.00 \\
\hline 11 & Loulé & Morgado da Tor (LLE-450+LLE-10) & Quaternary & $\mathrm{I}+\mathrm{Q}$ & 210000.00 & 23900.00 \\
\hline 12 & Faro & Telheiro (3673/FAR-6+Far-7) & Callovian & $\mathrm{Cc}+\mathrm{I}$ & 218000.00 & 16400.00 \\
\hline 13 & Faro & Cancela (FAR-5) & Callovian & $\mathrm{Cc}+\mathrm{I}$ & 219900.00 & 16300.00 \\
\hline $14 \mathrm{a}$ & Tavira & Montes e Lagares nº 1 (3676/TVR-7) & Rhaetian / Hettangian & I & 229400.00 & 20900.00 \\
\hline $14 \mathrm{~b}$ & Tavira & Espartosa (3675/TVR-9) & Rhaetian / Hettangian & I & 229100.00 & 20900.00 \\
\hline 15 & Tavira & Fonte do Bispo (TVR-24) & Rhaetian / Hettangian & $\mathrm{I}+\mathrm{Dol}$ & 233100.00 & 21200.00 \\
\hline $16 \mathrm{a}$ & Tavira & Marco (TVR-26) (?) & Rhaetian / Hettangian & I & 243700.00 & 21700.00 \\
\hline $16 b$ & Tavira & Marco (TVR-26) (?) & Rhaetian / Hettangian & I & 233000.00 & 20700.00 \\
\hline $17 \mathrm{a}$ & Tavira & Julião (TVR-10) & Rhaetian / Hettangian & $\mathrm{I}$ & 235100.00 & 20900.00 \\
\hline $17 \mathrm{~b}$ & Tavira & Julião 1 (3711/TVR-11) & Rhaetian / Hettangian & I & 235000.00 & 20900.00 \\
\hline $17 \mathrm{c}$ & Tavira & Julião 2 (3777/TVR-12) & Rhaetian / Hettangian & I & 234900.00 & 20900.00 \\
\hline
\end{tabular}

Notes: (1) According to ICS - International Chronostratigraphic Chart v2014/02; (2) Cc - Calcite; Dol - Dolimite; I - Illite; K - Kaolinite; Q - Quartz; (3) Portugal Military Coordinate System Datum Lisboa 


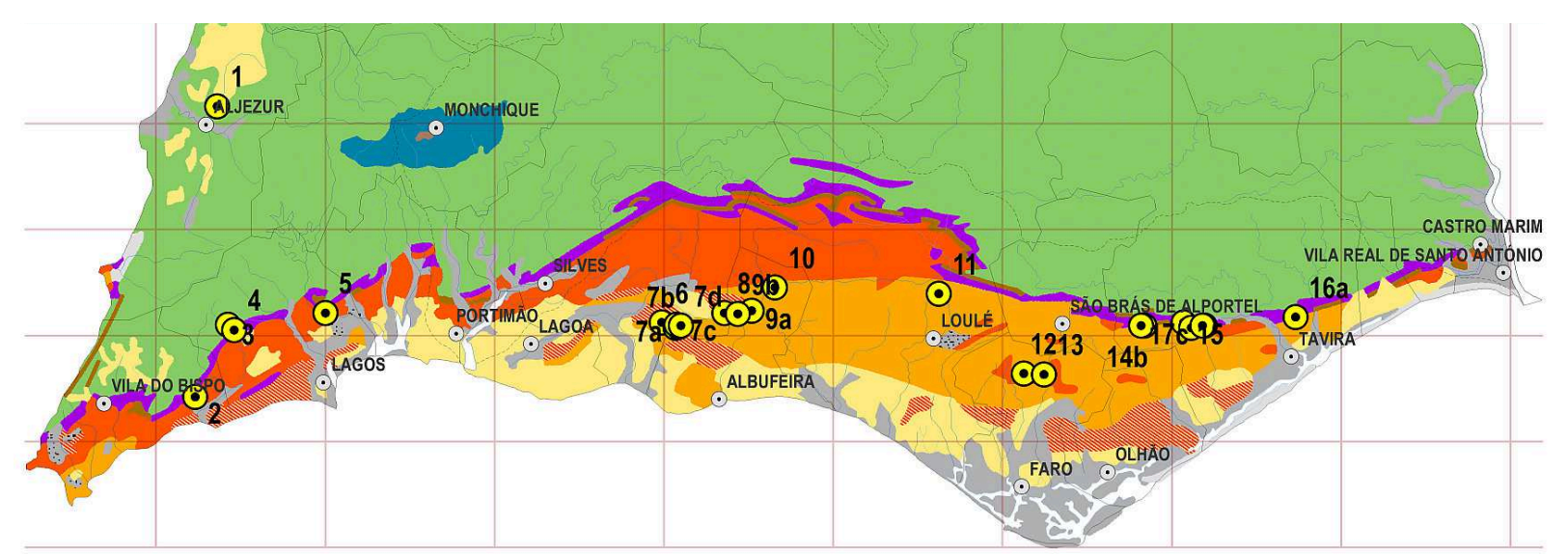

Fig. 1 - Location of the clay quarries present in 1985 study [19] superimposed to the lithological map of the Algarve region (adapted from [20]) - Notation: Green - shales, greywackes (Carboniferous period); Purple - red sandstones, marls, calcic and dolomitic rocks (transition from Triassic to Jurassic period); Red - marls, calcic and dolomitic rocks (Jurassic period); Orange - sandstones, conglomerates, calcic and dolomitic rocks and marls (Jurassic period); Pink - sandstones, conglomerates, calcic and dolomitic rocks and marls (Paleogene period); Yellow - sandstones, sands (Neogene period); Grey - gravels and sands (Neogene period).

From Figure 1 one can observe that apart of exploration zone n.1, all other clay quarries studied are located in the «Barrocal» region. According to the researchers' conclusions, which can be observed in Table 1, the clay samples studied have a mineralogy dominated by the illite clay mineral, also being observed, but in small amounts, the presence of kaolinite, dolomite, calcite and quartz. This evidence is consistent with a sedimentogenesis process based in a marine environment, which is the case of «Barrocal» region, located in Algarve sedimentary basin. From the chronostratigraphy analysis of the exploration zones the researchers concluded that the most important clay quarries were located in geologic formations from the Mesozoic era. And among those, the clay quarries located in formations from the Rhaetian / Hettangian age, in the transition from Triassic to Jurassic period, present higher predominance of the illite clay mineral [19].

The predominance of illite clay mineral was the primary factor to determine which clay quarry should be used for collecting clayish earth for the development of this study since clayish earth with illite predominance is characterized by a significant water vapor adsorption capacity, combined with low swelling when wetted. These characteristics are due to ilite alumino-silicate crystalline structure arranged in a succession of tetrahedron/octahedron/tetrahedron layers, with a interlayer space mainly occupied by potassium cations responsible for the lowered swelling [3,4]. These properties are most important for indoor plastering because maximize the moisture buffering capacity of the plaster and simultaneously mitigate the chance of the occurrence of shrinkage cracking during their drying.

Other key factor was to find, within the group of clay quarries with highest illite concentration factor, a still currently active exploration zone that had the equipment and availability for extracting, prepare and supply the amount of clayey soil needed for the present ongoing research on earthen-based plasters. According with this criteria it was possible to select a clay quarry in close proximity to the clay quarry referenced as $n^{\circ} 17$ in previously mentioned study from 1985 [19]. This clay quarry integrate a group of still currently active exploration zone comprising also the clay quarries referenced as $\mathrm{n}^{\circ} 14,15,16$ (Figure 1).

\section{Materials}

The clayish earth was extracted from the selected clay quarry and was mechanically disaggregated and sieved at $2 \mathrm{~mm}$. The siliceous sand selected for developing this experiment was extracted from a quarry located in Santiago do Cacém, in Setubal region, South West cost of Portugal. The particle size distribution of both the disaggregated clayish earth and the selected sand was analyzed by dry sieving, as used for mortars formulation, according to standard EN 1015-1 [21] and is presented in Figure 2. 


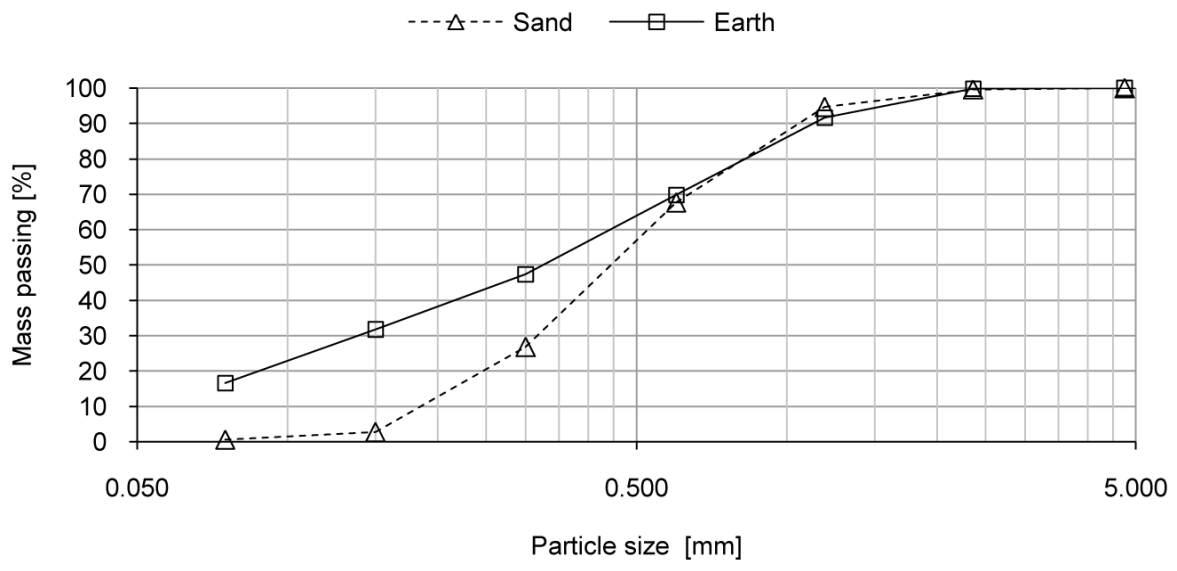

Fig. 2 - Particle size distribution curves of clayish earth and sand by dry sieving

In order to verify the effective predominance of illite clay mineral the mineralogical characterization of the clayish earth was carried out trough X-ray diffraction analysis (XRD), and complemented by thermogravimetric and differential thermal analysis (TGA-DTA).

X-ray diffraction (XRD) was obtained with a Phillips PW3710 X-ray diffractometer using Fe-filtered Co K $\alpha$ radiation, with $35 \mathrm{kV}$ and $45 \mathrm{~mA}$, speed of $0.05 \%$, from 3 to $74^{\circ} 2 \theta$. Two types of fractions were analyzed: the fraction corresponding to the clayish earth as collected, designated as overall fraction and obtained by grinding the material to pass in a $106 \mu \mathrm{m}$ sieve, and a fraction designated as fine fraction, which has a higher clay concentration and was obtained from the fines of the disaggregated material passing a $75 \mu \mathrm{m}$ sieve. The overall fraction was also used for thermal analysis (TGA-DTA) performed in a Setaram TGA-DTA analyzer, under argon atmosphere, with heating rate of $10^{\circ} \mathrm{C} / \mathrm{min}$, from room temperature to $1000^{\circ} \mathrm{C}$.

Figure 3 presents the diffractograms of the two fractions analyzed with the indication of the crystalline phases identified, which were obtained by comparison with the International Centre for Diffraction Data Powder Diffraction Files (ICDD PDF).



Fig. 3 - X-ray diffraction patterns of clayish earth: overall fraction (OF) and fine fraction (FF). Notation: D - dolomite; F - feldspar (microcline); H - hematite; K - kaolinite; M - illite; Q - quartz. 
From Table 2 it can be observed that quartz and illite are the predominant minerals present in the clayish earth. Dolomite and kaolinite are also detected with small amounts of an iron oxide (hematite) and possible a feldspar (microcline). Besides dolomite, no other carbonates were detected.

Table 2 - Mineralogical composition of the clayish earth overall and fine fractions.

\begin{tabular}{lcc}
\hline \multirow{2}{*}{ Mineral phases } & \multicolumn{2}{c}{ Clayish earth } \\
\cline { 2 - 3 } & Overall Fraction & Fine Fraction \\
\hline Dolomite $\left(\mathrm{CaMg}\left(\mathrm{CO}_{3}\right)_{2}\right)$ & $+/++$ & +++ \\
Feldspar $\left(\right.$ microcline- $\left.\left.\mathrm{KAlSi}{ }_{3} \mathrm{O}_{8}\right)\right)$ & $?$ & + \\
Hematite $\left(\mathrm{Fe}_{2} \mathrm{O}_{3}\right)$ & + & $+/++$ \\
Kaolinite $\left(\mathrm{Al}_{2} \mathrm{Si}_{2} \mathrm{O}_{5}(\mathrm{OH})_{4}\right)$ & $+/++$ & $++/+++$ \\
Illite $\left(\left(\mathrm{K}, \mathrm{H}_{3} \mathrm{O}\right)(\mathrm{Al}, \mathrm{Mg}, \mathrm{Fe})(\mathrm{Si}, \mathrm{Al})_{4} \mathrm{O}_{10}\left[(\mathrm{OH})_{2},\left(\mathrm{H}_{2} \mathrm{O}\right)\right]\right)$ & $++/+++$ & $++/+++$ \\
Quartz $\left(\mathrm{SiO}_{2}\right)$ & $++/+++$ & + \\
\hline
\end{tabular}

Peak intensity: ++++ very abundant (predominant compound); +++ abundant; ++ present; + small amount; - undetected; ? doubts in presence.

Figure 4 presents the corresponding TGA-DTA curves obtained for the overall fraction. The TGA-DTA curves obtained agree with the mineralogical composition obtained (Table 2), with three important weight losses at temperatures ranging from 20 to $200{ }^{\circ} \mathrm{C}, 350$ to $650^{\circ} \mathrm{C}$ and 650 to $850{ }^{\circ} \mathrm{C}$. The first two correspond to the decomposition of clay minerals illite and kaolinite, respectively, being the last one due to decarbonation of dolomite.

From the mineralogical analysis it can be concluded that the clayish earth studied present similarities with the clay materials studied in 1985 by the multidisciplinary team from the governmental institutions [19], being illite the main clay mineral present.

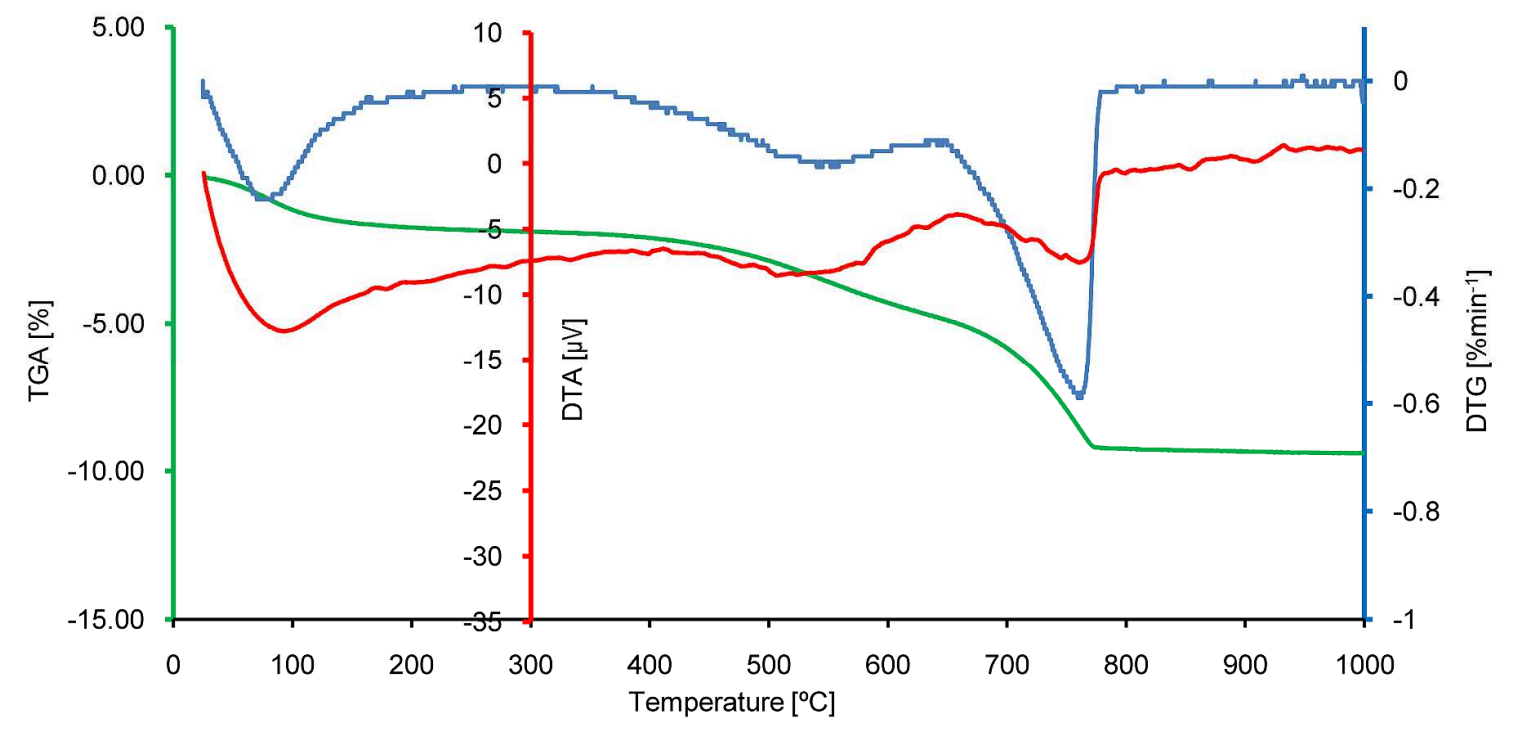

Fig. 4 - Thermal analysis curves of clayish earth (TGA - Thermogravimetric curve; DTG - Derivative thermogravimetric curve; DTA — Differential thermal analysis curve).

\section{Mortars Formulation and Fresh State Characterization}

Since this study aims to assess how clayish earth and sand ratio can influence physical and mechanical properties of plasters, four mortars were formulated with different volumetric ratios of clayish earth and siliceous sand, specifically $1: 2,1: 2.5,1: 3$ and 1:4, referenced respectively as E1S2, E1S2.5, E1S3 and E1S4. The standard DIN 18947 [11] was followed for preparing and mixing the mortars, as well 
as for fresh state characterization. The mortars were prepared with the minimum amount of water needed in order to achieve the flow table consistency [22] defined in the DIN $18947(175 \pm 5 \mathrm{~mm})$ and ensuring a very good workability. Each mortars formulation is registered in Table 3, in terms of both volumetric and weight percentages of clayish earth, sand and water contents. Wet density and flow table consistency were also assessed.

Table 3 - Volumetric and weight composition and fresh state mortars characterization

\begin{tabular}{|c|c|c|c|c|c|c|c|c|}
\hline \multirow[b]{2}{*}{ Mortar } & \multicolumn{3}{|c|}{ Volume } & \multicolumn{3}{|c|}{ Weight } & \multirow[b]{2}{*}{$\begin{array}{l}\text { Density (c) } \\
{\left[\mathrm{kg} / \mathrm{m}^{3}\right]}\end{array}$} & \multirow[b]{2}{*}{$\begin{array}{l}\text { Consistency (d) } \\
{[\mathrm{mm}]}\end{array}$} \\
\hline & $\begin{array}{l}\text { Earth } \\
{[\%]}\end{array}$ & $\begin{array}{l}\text { Sand } \\
{[\%]}\end{array}$ & $\begin{array}{l}\text { Water (a) } \\
{[\%]}\end{array}$ & $\begin{array}{l}\text { Earth } \\
{[\%]}\end{array}$ & $\begin{array}{l}\text { Sand } \\
{[\%]}\end{array}$ & $\begin{array}{l}\text { Water }(b) \\
{[\%]}\end{array}$ & & \\
\hline$\overline{E 1 S 2}$ & 33.3 & 66.7 & 18.8 & 29.3 & 70.7 & 12.5 & 2111.5 & 172.3 \\
\hline E1S2.5 & 28.7 & 71.3 & 17.7 & 25.0 & 75.0 & 11.6 & 2115.2 & 162.3 \\
\hline E1S3 & 25.0 & 75.0 & 19.6 & 21.6 & 78.4 & 12.8 & 2130.7 & 173.2 \\
\hline E1S4 & 20.0 & 80.0 & 20.4 & 17.1 & 82.9 & 13.3 & 2097.3 & 171.2 \\
\hline
\end{tabular}

(a) Percentage of volume added considering the total volume of clayish earth and sand

(b) Percentage of mass added considering the total mass of clayish earth and sand

(c) Fresh state density

(d) Flow table consistency

\section{Hardened State Characterization}

The hardened state characterization of the mortars also followed the DIN 18947 [11], EN 1015 standards $[23,24,25]$ and test procedures currently used by the research team [26]. Prismatic $160 \mathrm{~mm}$ x $40 \mathrm{~mm}$ x $40 \mathrm{~mm}$ samples and circular $90 \mathrm{~mm}$ diameter and $20 \mathrm{~mm}$ thick samples were prepared in metallic molds, as well as samples of $20 \mathrm{~mm}$ mortar layer applied on a surface of $295 \mathrm{~mm}$ x $195 \mathrm{~mm}$ of hollow bricks. The mortars were assessed in terms of linear drying shrinkage [11], density [23], flexural and compressive strength [24], adhesive strength [25], as well as thermal conductivity [26] and water vapor adsorption and desorption capacity [11]. The first four tests used the prismatic samples and the adhesive strength test were carried out with mortar layer on brick samples, while for thermal conductivity test the circular samples were used.

For the dynamic adsorption and desorption test, conducted according to the DIN 18947 [11], three plaster samples were produced for each mortar formulation, with a surface area of $1000 \mathrm{~cm}^{2}(500 \mathrm{~mm}$ x $200 \mathrm{~mm}$ ) and a thickness of $15 \mathrm{~mm}$. Each sample was prepared in a metallic mold to guarantee that adsorption and desorption would occur only in the top exposed surface.

The samples were stabilized in a climatic chamber (Figure 5) at 50\% relative humidity $(\mathrm{RH})$ and $23^{\circ} \mathrm{C}$. After the stabilization of the samples the climatic chamber condition was set to $80 \% \mathrm{RH}$ for the adsorption test phase. The samples were weighted at time intervals defined on the standard, respectively: $0.5 \mathrm{~h}, 1.0 \mathrm{~h}, 3 \mathrm{~h}, 6 \mathrm{~h}$ and $12 \mathrm{~h}$. The adsorption test was extended till $24 \mathrm{~h}$, beyond the $12 \mathrm{~h}$ interval defined in the standard, in order to achieve a more comprehensive understanding of the adsorption behavior of the samples. After $24 \mathrm{~h}$ the samples were weighted and the condition of the chamber was changed back to $50 \% \mathrm{RH}$, forcing the samples to a desorption phase, that was assessed with the same time interval protocol during another period of $24 \mathrm{~h}$. 


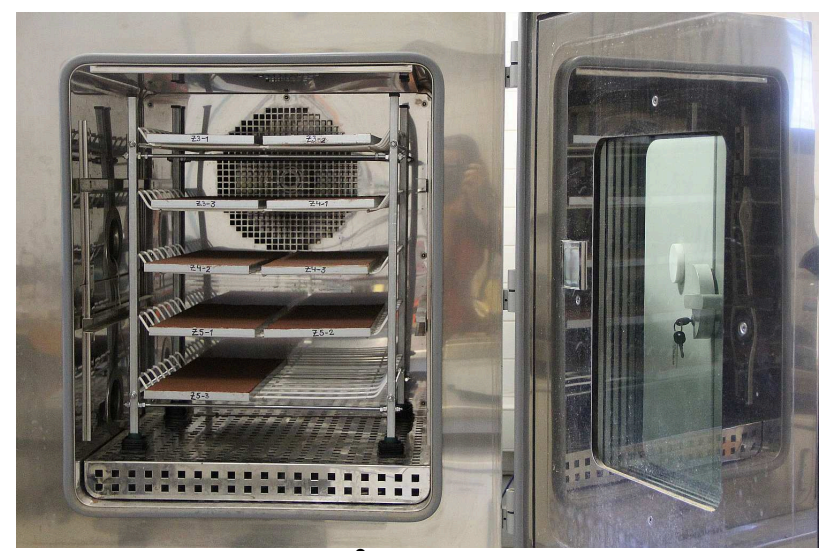

Fig. 5 - Climatic chamber with the $1000 \mathrm{~cm}^{2}$ mortar samples for adsorption and desorption tests

\section{Results and Discussion}

The hardened state characterization allowed to confirm that all the mortars present a significantly low linear drying shrinkage, with less than $1.5 \%$ for mortar E1S2, the one with the highest content of clayish earth (Figure 6). No cracking was observed on any of the samples during this study, even in the samples prepared for the adhesive strength test, where a $20 \mathrm{~mm}$ mortar layer was applied on hollow bricks. These results are consistent with the low expansibility of the clayish earth used, which has a mineralogy dominated by illite clay mineral. It can be also noticed, as expected, that the decrease of clayish earth ratio in mortars formulation (from E1S2 to E1S4) promote the decrease of plasters' linear drying shrinkage.

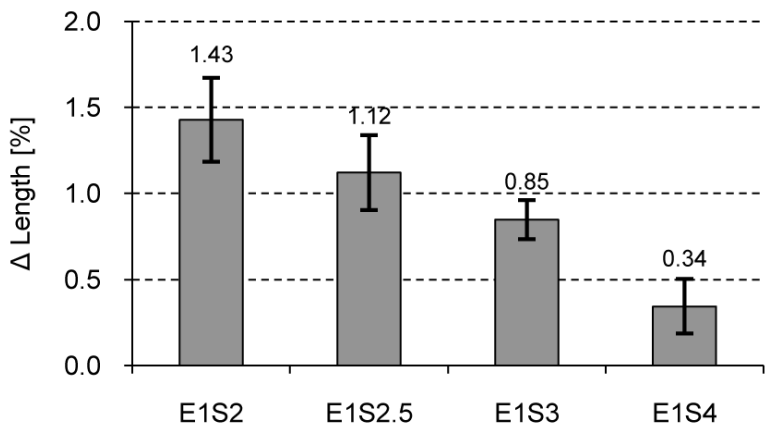

Fig. 6 - Linear drying shrinkage

Regarding hardened state bulk density (Figure 7) and according to DIN 18947 [11] it can be notice that all the mortars falls within bulk density class 2.0 (from $1.81 \mathrm{~kg} / \mathrm{dm}^{3}$ till $2.0 \mathrm{~kg} / \mathrm{dm}^{3}$ ). Although all mortars present almost near the same values of bulk density, it is however possible to perceive a subtle tendency of bulk density increase with the increase of clayish earth ratio in mortars formulation.

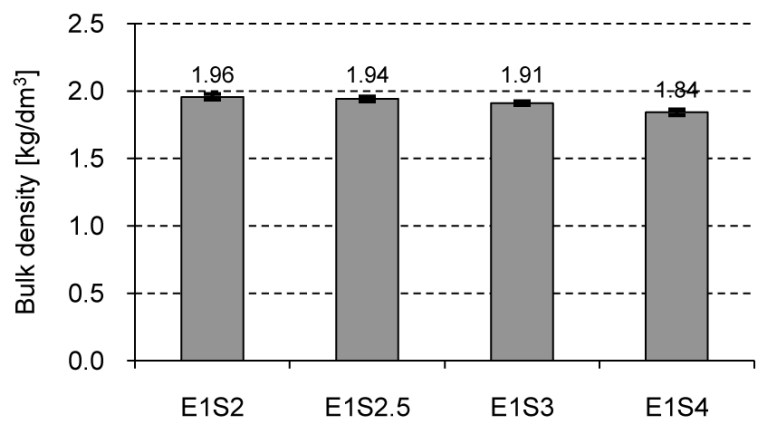

Fig. 7 - Hardened state bulk density 
The thermal conductivity results (Figure 8) showed that the two mortars with higher clayish earth ratios (E1S2 and E1S2.5) present also higher thermal conductivity values. These increments of the thermal conductivity do follow the mortars bulk density tendency.

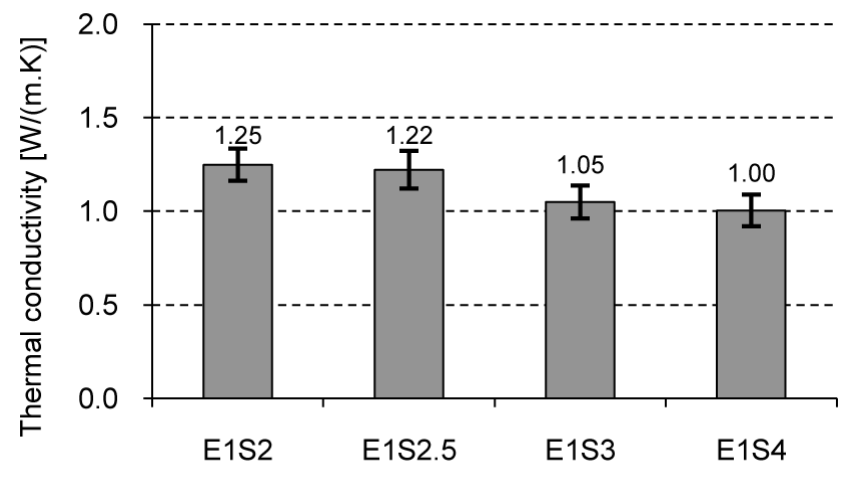

Fig. 8 - Thermal conductivity

The mechanical results (Figure 9) showed that regarding flexural and compressive strength, according to DIN 18947 [11], the four mortars did not achieved the minimum values of mechanical resistance defined in the class S-I (compressive strength $\geqslant 1.0 \mathrm{~N} / \mathrm{mm}^{2}$ and flexural strength $\geqslant 0.3$ $\mathrm{N} / \mathrm{mm}^{2}$ ). Nevertheless it is possible to notice that the two mortars with higher clayish earth contents (E1S2 and E1S2.5) almost reached the minimum values of mechanical resistance defined for that class. These results also showed that flexural and especially compressive strength tend to increase with the increase of clayish earth ratios in mortars formulation.

Regarding adhesion strength the mechanical tests results showed that, according to DIN 18947 [11], all the four mortars achieve the minimum values of adhesion strength defined in the class S-I ( $\geqslant 0.05 \mathrm{~N} / \mathrm{mm}^{2}$ ), which are promising results, considering that adhesion strength is one of the most important mechanical properties for plastering mortars. In Figure 9 it is also possible to observe that the mortars adhesion strength does not follow exactly the tendency of decrease with the increase of sand contents in the mortars composition, noticed for the other properties. In fact the results of adhesion strength are quite stable.

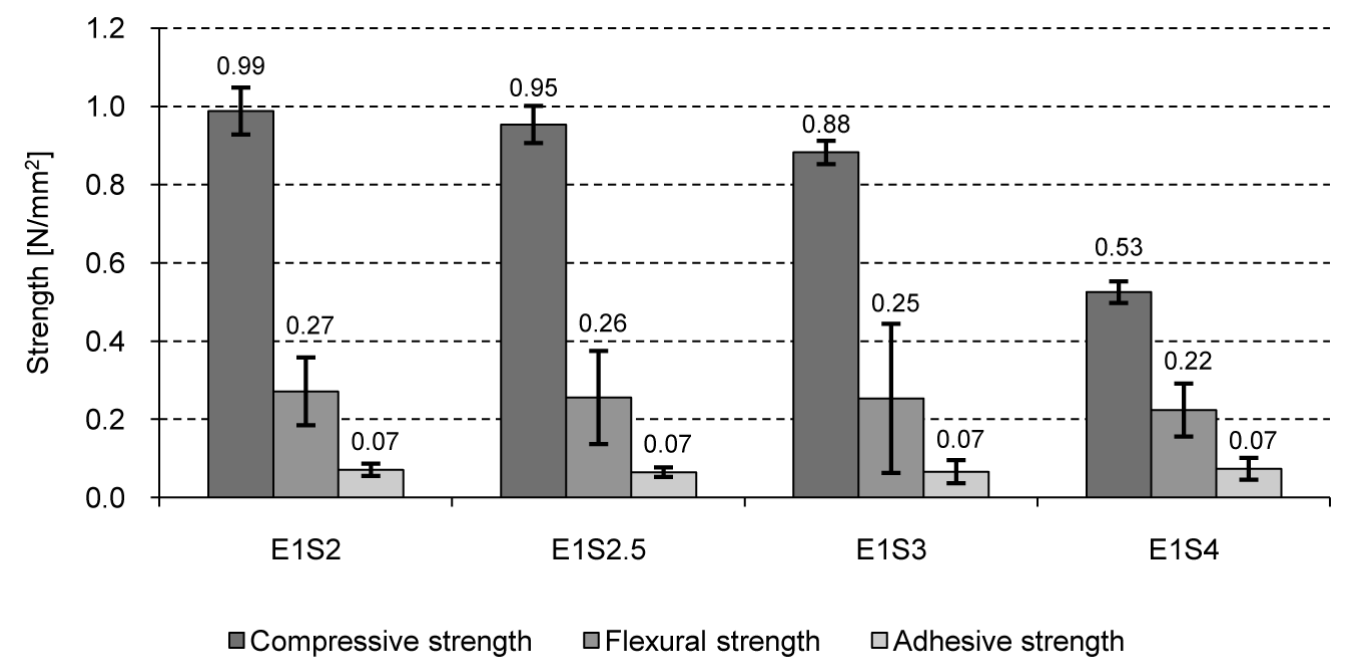

Fig. 9 - Compressive, flexural and adhesive strength

The results of the dynamic adsorption and desorption test (Figure 10) indicate that all four mortars present a very high adsorption and desorption capacity. According to DIN 18947 [11] all mortars 
assessed in this study achieved adsorption values within the water adsorption class WS-III, the higher adsorption class defined in the standard $\left(\geqslant 60.0 \mathrm{~g} / \mathrm{m}^{2}\right.$ of adsorbed water vapor after $12 \mathrm{~h}$ at temperature of $23^{\circ} \mathrm{C}$ and a $\mathrm{RH}$ of $80 \%$ ).

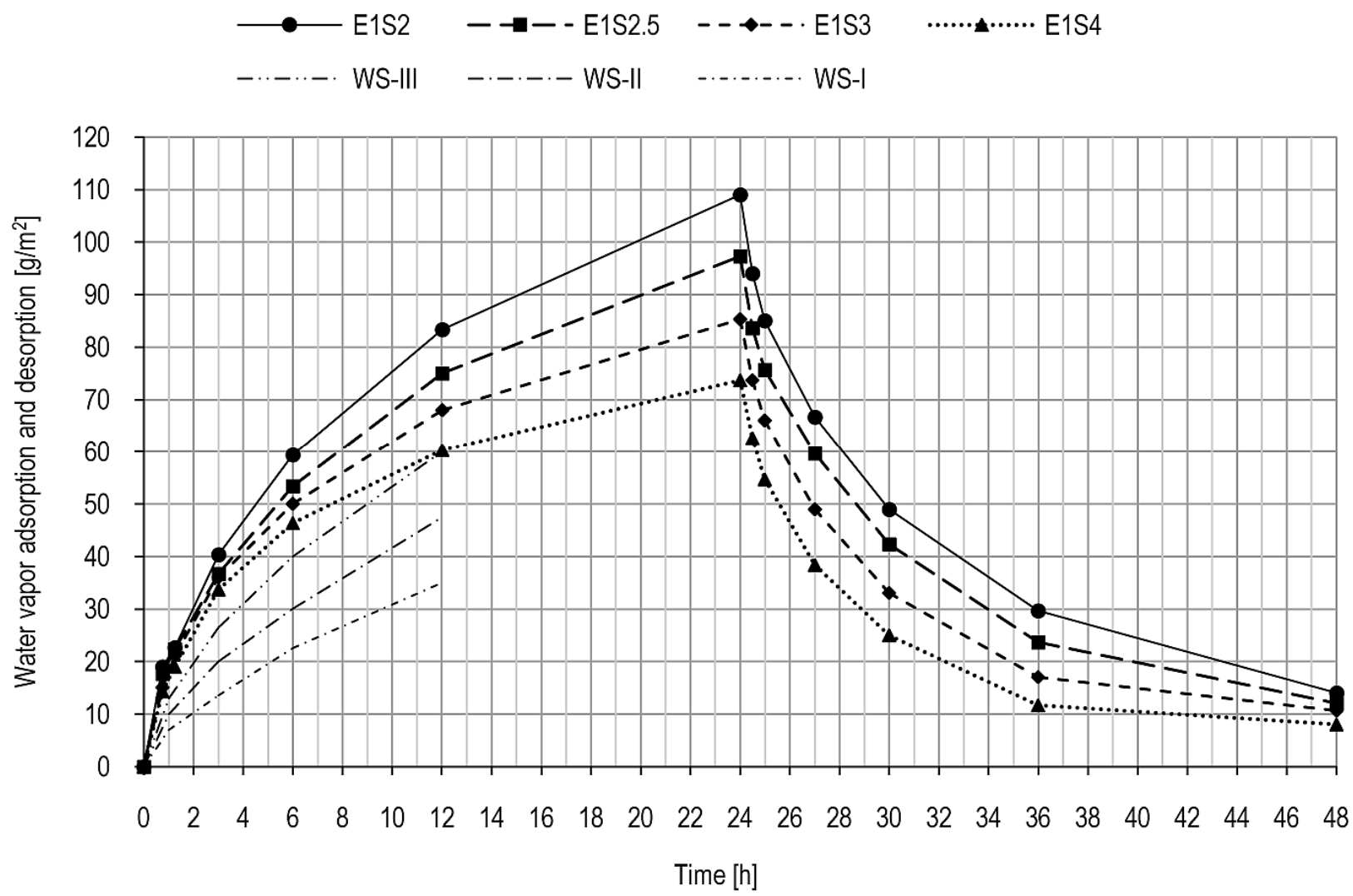

Fig. 10 - Water vapor adsorption and desorption and class limits of the standard

The high adsorption and desorption capacity of the assessed mortars is consistent with the clayish earth mineralogy, that present illite as the prevalent clay mineral, being characterized by a significant water vapor adsorption capacity. As expected, it can be also notice that the increase of adsorption and desorption capacity is associated with the increase of clayish earth contents in mortars formulation. This association could be better perceived in Figure 11, which presents the positive correlation between the clayish earth weight ratio of mortars formulation and the plaster water vapor adsorption capacity for the $12 \mathrm{~h}$ time interval, according to DIN 18947 [11].

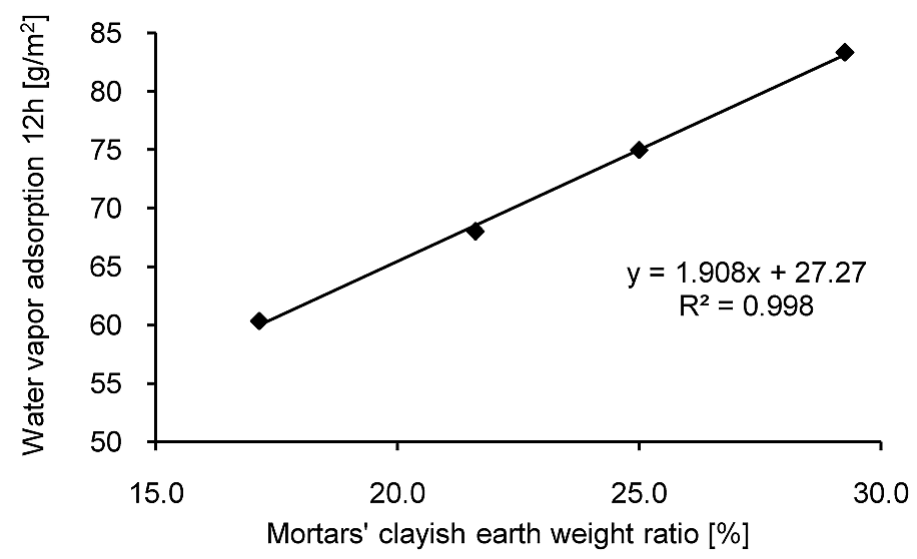

Fig. 11: Correlation of mortars' clayish earth weight ratio and plaster water vapor adsorption after $12 \mathrm{~h}$ 
The extraordinary adsorption capacity of the assessed earth-based plasters become even more evident when considering mortar E1S2, the one with higher clayish earth contents, which achieved a water vapor adsorption over $83 \mathrm{~g} / \mathrm{m}^{2}$ after $12 \mathrm{~h}, 38 \%$ higher than the $60 \mathrm{~g} / \mathrm{m}^{2}$ limit defined in class WS-III of the DIN 18947 [11]. These results have the utmost importance since this high water vapor adsorption capacity allows earth-based plasters to act as a moisture buffer, contributing in a passive way to balance the RH of the indoor environment of buildings and, therefore, promoting comfort and health of inhabitants.

The results of the dynamic adsorption and desorption test also show that all the four mortars have a similar dynamic behavior of adsorption and desorption, however showing some desorption delay, or hysteresis, being this effect most pronounced on the mortars with higher clayish earth contents (over $12 \%$ ). More research is advisable on this subject since this desorption delay can generate a lag effect between consecutive cycles of adsorption and desorption, which could lead, over a certain period of time, to the decrease of adsorption and desorption capacity of the plaster, or even to its full moisture saturation.

Although the increase of international interest in earth-based plasters, there still are very few references dealing with the characterization of clay plaster in international scientific journals, thus becoming difficult an extensive comparison of data between different studies. Nevertheless, some of the present results may be compared with the partial results of similar researches that followed the same test protocol, or comparable ones.

The significantly low linear drying shrinkage of the assessed mortars (less than $1.5 \%$ ) can be compared with five earth-based mortars characterized by Delinière et al. [12], which were formulated with similar proportions of clayish earth and sand and presented higher drying shrinkage (between 1.5 and $2.5 \%$ ) probably due to the different mineralogy of the clayish earths used, where illite is not the predominant clay mineral. Similar comparison can be made with the results obtained by Faria et al. [14], which assessed a ready-mixed earth-based mortar with addition of oat straw fibers (shrinkage less than 1\%), and Lima \& Faria [15] which characterized six mortar specifically formulated with different additions of oat straw fibers and typha fiber wool (shrinkage also less than 1\%). The mortars of both of these studies were prepared with proportions of clayish earth and siliceous sand similar to the mortars assessed in the present study. The clayish earth used in both studies was also extracted from the «Barrocal» region, in Algarve, and presented a mineralogical composition similar to the clayish earth used in the present study, which is consistent with the also low drying shrinkage results obtained.

The mechanical resistance results obtained in the present study can also be compared with the three studies previously mentioned. Regarding compressive and flexural strength, according to DIN 18947 [11], the five earth-based mortars characterized by Delinière et al. [12] clearly achieved the class S-II for compressive strength $\left(\geq 1.5 \mathrm{~N} / \mathrm{mm}^{2}\right)$ and the class S-I for flexural strength $(\geq 0.3$ $\mathrm{N} / \mathrm{mm}^{2}$ ), while in the present study results were significantly lower, being the four assessed mortars just close to reach the minimum values defined for class S-I either for compressive and flexural strength. Considering that the mortars from both studies were formulated with similar proportions of clayish earth and sand, and apart from any contribution that may come for subtle differences of the used sands, the different results of mechanical resistance obtained may be justifiable by the different mineralogy of the clayish earths used on each study. The other two studies, Faria et al. [14] and Lima \& Faria [15], presented mechanical resistance results, of compressive and flexural strength, quite similar to the results obtained in the present study, which is consistent with the fact of both studies were carried out considering similar mortar formulations, as well as a clayish earth extracted from a near location in the «Barrocal» region.

Regarding adhesive strength the results obtained by Delinière et al. [12], following DIN 18947 [11] test protocol, were highly dispersed and much lower than the limit values given by the class S-I of the standard $\left(\geqslant 0.05 \mathrm{~N} / \mathrm{mm}^{2}\right)$. This lead the researchers to test a modification of the protocol procedure, which mainly consist in previously wetting the support surface with a suspension (liquid mixture) of the clayish earth and water. This protocol modification clearly improved the 
adhesive strength results. Although the present study only had assessed the mortars adhesive strength according to DIN 18947 [11] test protocol, the obtained results were quite similar for the four assessed mortars, presenting low standard deviation, and surpassed minimum values defined in the class S-I of the standard. Faria et al. [14] and Lima \& Faria [15] also carried out the test according to DIN 18947 [11] and presented adhesive strength results similar to the present study, although both with higher values - specially the results of Faria et al. [14] which achieved the class S-II of the standard $\left(\geqslant 0.10 \mathrm{~N} / \mathrm{mm}^{2}\right)$. This subject is clearly open to discussion, eventually needing more research on the matter.

Concerning the adsorption and desorption capacity test, besides the results of Faria et al. [14] and Lima \& Faria [15], that followed the same DIN 18947 [11] test procedures, it may be also possible to establish some comparison with the results obtained by Maddison et al. [5]. The first two mentioned studies also obtained a very high water vapor adsorption and desorption, both surpassing the adsorption values defined in the highest adsorption class (WS-III) of the DIN 18947 [11] ( $\geqslant 60.0$ $\mathrm{g} / \mathrm{m}^{2}$ of adsorbed water vapor after $12 \mathrm{~h}$ at temperature of $23^{\circ} \mathrm{C}$ and a $\mathrm{RH}$ of $80 \%$ ). These results are quite similar with the ones of the present study and are consistent with the use of a clayish earth with similar mineralogical composition.

Maddison et al. [5] followed a similar test protocol but carried out at a slightly lower temperature condition (at $21^{\circ} \mathrm{C}$ instead of the $23^{\circ} \mathrm{C}$ used in the present study) and also with significantly smaller and thin samples, with an exposed area of $200 \mathrm{~cm}^{2}$ and a thickness of $10 \mathrm{~mm}$, instead of the samples with an area of $1000 \mathrm{~cm}^{2}$ and thickness of $15 \mathrm{~mm}$, defined in the DIN 18947 [11], and used in the present and other mentioned studies. The adsorption and desorption results presented relatively low values, with all of the nine assessed mortars showing adsorptions between 30 and $40 \mathrm{~g} / \mathrm{m}^{2}$ of water vapor after $12 \mathrm{~h}$, which is approximately half of the adsorption capacity presented by the mortars assessed in this study. These comparably lower results may be partially justified by the reduced area and thickness of the samples used and by the slightly lower temperature condition, as well as by the mineralogical composition of the clayish earth used, in which illite clay mineral is still abundant but have not the same predominance has it has in the clayish earth from «Barrocal», being founded a higher concentration of kaolinite clay mineral, characterized by lower adsorption $[3,4]$.

\section{Conclusion}

The results from this study showed that all the assessed earth-based plasters presented a significantly low linear drying shrinkage $(<1.5 \%)$ along with an extraordinary adsorption and desorption capacity, surpassing the highest adsorption class defined in DIN $189470\left(\geq 60 \mathrm{~g} / \mathrm{m}^{2}\right)$. This fact is of the utmost importance revealing this plasters' capacity to act as a moisture buffer, contributing to balance the relative humidity of the indoor environment of buildings and, therefore, promoting comfort and health of inhabitants.

Linear drying shrinkage and water vapor adsorption results present a positive correlation with mortars' clayish earth contents and are consistent with the clayish earth mineralogical analysis, that confirmed illite as the prevalent clay mineral. This mineral can be characterized by a significant water vapor adsorption capacity along with low swelling when wetted.

The mortars revealed a similar dynamic behavior of adsorption and desorption, proportional to mortars clayish earth contents; however, showing some desorption delay. It is expectable that in consecutive cycles of adsorption and desorption this delay can lead to the decrease of adsorption capacity of the plasters, or even to their moisture saturation. More research is needed in this subject in order to assess the extent of the desorption delay effect over long periods in real conditions.

Regarding mechanical resistance, although the promising results of the adhesion test (one of the most important properties for plasters), the flexural and compressive strength results suggest that the mechanical resistance of these mortars should be slightly improved, since the assessed mortars did not achieved the minimum values of mechanical resistance defined in DIN 18947 [11]. 
Considering the positive tendency between the mortars clayish earth contents and mechanical resistance, as well as the mortars low shrinkage, the mechanical resistance improvement may be achieved through the formulation of mortars with higher concentrations of clayish earth content, which expectably also will lead to even higher plaster adsorption capacity. Alternatively the mechanical resistance improvement may be also obtained through the addition of natural fibers to mortars formulation. Both those options will be investigated in future research.

This research contributed to increase certainty regarding the potential of earthen plasters based on illitic soils from «Barrocal» region of Algarve and their contribution to balance the relative humidity of the indoor environment of buildings. Furthermore, considering the wide availability and diversity of clayish earth, ecological benefits can be foreseen from the replication of this research for clayish soils from other regions, which will promote a more frequent use of locally produced earth-based plasters and, therefore, allow the mitigation of the impact of long distance transportations.

\section{References}

[1] Melià, P.; Ruggieri, G.; Sabbadini, S.; Dotelli, G. (2014) - Environmental impacts of natural and conventional building materials: a case study on earth plasters. J. Clean. Prod., 2014, p.179-186.

[2] Minke, G. (2006) - Building with earth: design and technology of a sustainable architecture. Basel: Birkhauser - Publishers for Architecture, 2006. 199 p. ISBN-13: 978-3-7643-7477-8. ISBN-10: 3-7643-7477-2.

[3] Botelho-Costa, J. (1973) - Soil characterization and formation (in Portuguese). $7^{\text {a }} 7$ th ed. Lisbon: Fundação Calouste Gulbenkian, 2004. ISBN 972-31-0073-8.

[4] Gomes, C. (1988) - Clays: what they are and for what they serve (in Portuguese). 1st ed. Lisbon: Fundação Calouste Gulbenkian, 1988.

[5] Maddison, M.; Mauring, T.; Kirsimae, K.; Mander, U. (2009) - The humidity buffer capacity of clay-sand plaster filled with phytomass from treatment wetlands. Build. Environ., 2009, p.1864-1868.

[6] Liuzzi S, Hall MR, Stefanizzi P, Casey SP (2013) - Hygrothermal behaviour and relative humidity buffering of unfired and hydrated lime-stabilised clay composites in a Mediterranean climate. Build. Environ., 61, p. 82-92.

[7] Moret-Rodrigues A, Canha-Piedade A, Braga A (2009) - Thermal in buildings (in Portuguese). 1st ed. Alfragide: Orion editions. ISBN 978-972-8620-13-4.

[8] WHO World Health Organization (2009) Guidelines for indoor air quality: dampness and mould. Copenhagen: World Health Organization - Regional Office for Europe. ISBN 978-92-890-4168-3.

[9] Lamble SP, Corsi RL, Morrison GC (2011) - Ozone deposition velocities, reaction probabilities and product yields for green building materials. Atmospheric Environ., 45(38), p. 6965-6972.

[10] Darling EK, Cros CJ, Wargocki P et al (2012) - Impacts of a clay plaster on indoor air quality assessed using chemical and sensory measurements. Build Environ., 57, p-370-376.

[11] DIN 18947: 2013 - Earth plasters - Terms and definitions, requirements, test methods (in German). Berlin: DIN - Deutsches Institut für Normung.

[12] Delinière, R.; Aubert, JE.; Rojat, F.; Gasc-Barbier, M. (2014) - Physical, mineralogical and mechanical characterization of ready-mixed clay plaster. Build. Environ., 2014, p.11-17.

[13] Lima J, Faria P (2014) - Earthen Plasters: The Potential of the Clayey Soils of Barrocal Region In Algarve. In 40th IAHS World Congress on Housing - Sustainable Housing Construction, Funchal, December 16-19, 2014. Proceedings, first edition, Coimbra: ITeCons, U-Coimbra, 2014. ISBN 978-989-98949-0-7. p.173. (CD-Rom ID-217, ISBN 978-989-98949-1-4). 
[14] Faria P, Santos T, Aubert J-E (2015) - Experimental characterization of an earth eco-efficient plastering mortar. Journal of Materials in Civil Engineering (in press), Doi: 10.1061/(ASCE)MT.1943-5533.0001363.

[15] Lima J, Faria P (2015) - Eco-efficient earthen plasters: The influence of the addition of natural fibers. In 2nd International Conference on Natural Fibers - From Nature to Market, Ponta Delgada, April 27-29, 2015. Proceedings, first edition, Braga: U-Minho, 2015. ISBN 978-989-98468-5-2. p.39. (CD-Rom ID-47, ISBN 978-989-98468-4-5).

[16] Manuppella, G. (1992) - General features of the Algarve geology - Mesozoic (in Portuguese). In Manuppella, Giuseppe [Coord.] -Geological chart of Algarve region: Scale 1:100.000. Explanatory note. Serviços de Geologia de Portugal, 1992.

[17] Kopp, E. [et al.] (1989) - Algarve soils and its characteristics: Overview (in Portuguese). 1st reprint. Faro: Departamento Regional de Agricultura do Algarve, 2000.

[18] Pinto-Gomes, C.; Paiva-Ferreira, R. (2005) - Flora and vegetation of Barrocal region in Algarve - Tavira-Portimão (in Portuguese). Faro: CCDR Algarve, 2005. 354 p. ISBN 972-95734-9-2.

[19] Manuppella, G. [et.al.] (1985) - Knowledge contribution of Algarve clays characteristics (in Portuguese). Porto: Estudos, Notas e Trabalhos do Serviço de Fomento Mineiro e Laboratório da DGGM. Tomo 27, 1985. p.59-75.

[20] Agência Portuguesa do Ambiente - Environmental Atlas (in Portuguese). [On-line]. Lisbon: APA, 2013. [Accessed 2013-10-09]. Available at $\mathrm{WWW:<URL:}$ http://sniamb.apambiente.pt/atlas/>.

[21] EN 1015-1:1998 - Methods of test for mortar for masonry; Part 1: Determination of particle size distribution (by sieve analysis). Brussels: CEN - European Committee for Standardization.

[22] EN 1015-3: 1999 - Methods of test for mortar for masonry; Part 3: Determination of consistence of fresh mortar (by flow table). Brussels: CEN - European Committee for Standardization.

[23] EN 1015-10: 1999 - Methods of test for masonry; Part 10: Determination of dry bulk density of hardened mortar. Brussels: CEN - European Committee for Standardization.

[24] EN 1015-11: 1999 - Methods of test for masonry; Part 11: Determination of flexural and compressive strength of hardened mortar. Brussels: CEN - European Committee for Standardization.

[25] EN 1015-12: 2000 - Methods of test for mortar for masonry; Part 12: Determination of adhesive strength of hardened rendering and plastering mortars on substrates. Brussels: CEN - European Committee for Standardization.

[26] Brás, A.; Leal, M.; Faria, P. (2013) - Cement-cork mortars for thermal bridges correction. Comparison with cement-EPS mortars performance. Construction and Building Materials, 49, 2013. p.315-327. http://dx.doi.org/10.1016/j.conbuildmat.2013.08.006 